\title{
Corrosive Behavior and Physic-Chemical Characterization of Filtration Tanks
}

\author{
Francisco Casanova-del-Angel \\ Instituto Politécnico Nacional, Ciudad de México, México \\ Email: fcasanova49@prodigy.net.mx
}

How to cite this paper: Casanova-del-Angel, F. (2017) Corrosive Behavior and Physic-Chemical Characterization of Filtration Tanks. Open Journal of Physical Chemistry, 7, 123-132.

https://doi.org/10.4236/ojpc.2017.74008

Received: June 20, 2017

Accepted: November 14, 2017

Published: November 17, 2017

Copyright $\odot 2017$ by author and Scientific Research Publishing Inc. This work is licensed under the Creative Commons Attribution International License (CC BY 4.0).

http://creativecommons.org/licenses/by/4.0/

\begin{abstract}
Most drinkable water supplied to the public in Mexico City comes from deep wells which extract water from the subsoil. Before being distributed, it is treated in steel filtration tanks. This water must be subject to evaluation through physic-chemical and bacteriological analyses in order to determine its quality. However, doubts always remain over the influence of the components of this water on the corrosive behavior of the filtration tanks. In light of this, this article studies the physic-chemical characterization values of water and presents the results. This has also enabled the analysis of the corrosion speed of filtration tanks components, boilers and water-cooled systems, where incrustations in pipes, obstructions and loss of heat transfer efficiency occur, rendering drinkable water bad tasting and, after some time, causing pitting corrosion although this type of corrosion only causes serious problems in the long term.
\end{abstract}

\section{Keywords}

Corrosion Speed, Steel, Spectrometry, Damage by Corrosion, Physic-Chemical Characterization

\section{Introduction}

During 2014 and 2015, an investigation was carried out into how the well water influences and affects the process of filtration of steel tanks [1]. Although we studied the microstructure of steel A284 Grade C and the depth of damage suffered by corrosion, we did not study the Physic-Chemical characterization of the process, nor was its influence was analyzed. And this is precisely what we will present here in this article. The water treatment plant in the study is shown in Figure 1. 


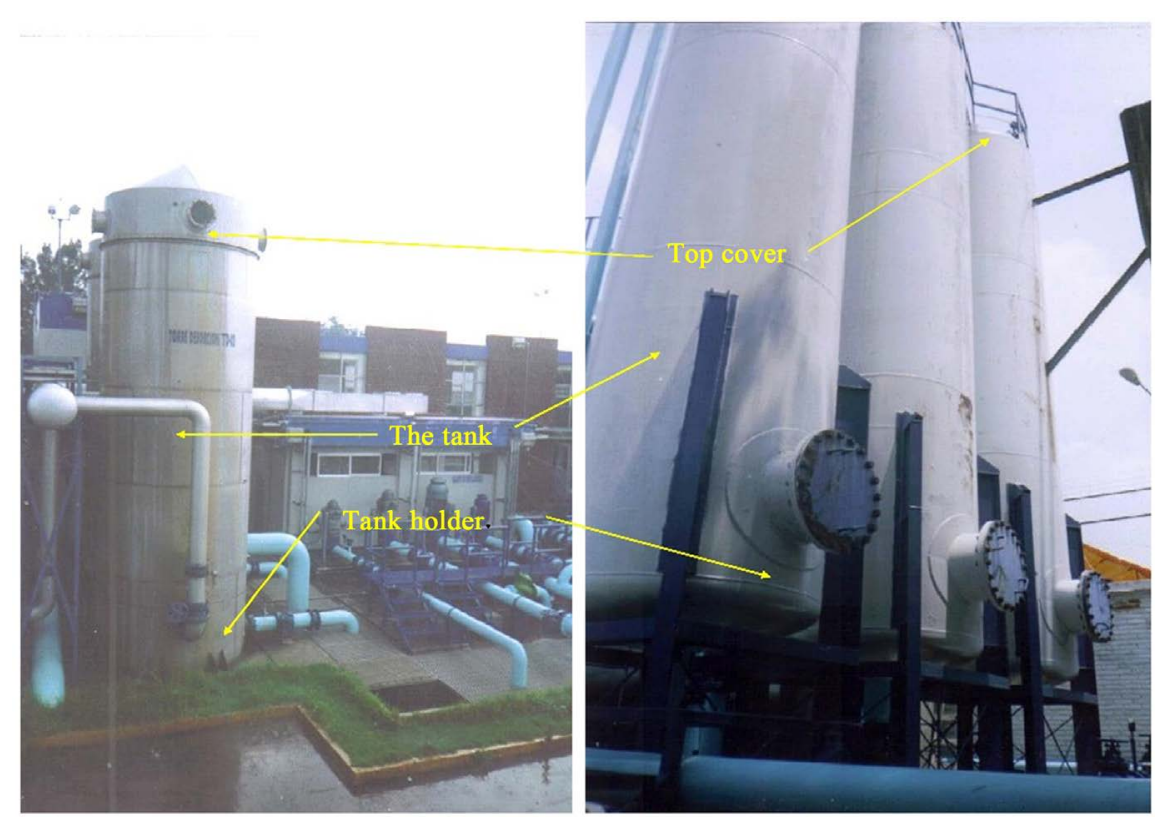

Figure 1. Potable water filtration steel tank.

Regarding control of incrustations, it is known that three conditions are required for them to be formed. First, oversaturation, which occurs when the concentration of dissolved ions such as $\mathrm{Ca}^{2+}, \mathrm{CO}_{3}^{2-}, \mathrm{Na}^{+}, \mathrm{Ba}^{2+}$, and $\mathrm{SO}_{4}^{2-}$ increases, exceeding normal limits of process water solubility. Second, kinetic acceleration, temperature shocks, mechanical or hydrodynamic forces, optimal $\mathrm{pH}$ conditions, and sudden pressure, when changes may accelerate kinetics of incrustations formation and the optimal surface; and third, non-uniform surfaces found in heat exchangers pipes. Optimal substrates promote adherence of inorganic microcrystal's and allow incrustation building.

Analysis on the mechanics of the damage and the damage by corrosion can be seen in [1]. The method used for assessment of corrosion speed of steels under study is weight loss undergone by a metal or alloy in contact with corrosive means cab be seen in [2] [3] [4].

Before presenting physic-chemical characterization, it is useful to present definitions of the main topics of this document: corrosion and physic-chemical characterization. We must do this, in order to fully understand its actual influence on the corrosive behavior of well water filtration tanks throughout their useful life.

Corrosion is: 1) damage of a metallic material as a result of a chemical attack by the environment; 2) chemical or electrolytic damage of a material, preferably metallic, due to its reaction to the surrounding environment; and/or 3) impairment of a metal through some means (aside from those which are purely metallic), due to a chemical or electrochemical reaction to the environment or damage of a metal by other means, aside from those which are purely metallic.

We may classify as humid corrosion: corrosion occurring when a liquid is present; and dry corrosion: corrosion caused by vapors or gases, generally re- 
lated to high temperatures and direct chemical or electrochemical reaction occurring when there is a reaction between the metal and other non-metallic elements or compounds. Corrosion by electrochemical reaction occurs when electricity conductive liquids (electrolytes) are present. Most corrosion is caused by liquids.

A metal may be corroded without being in contact with another metal. In this case, the various areas of the metal have various electrical potentials. This may occur due to differences in metallurgical properties of the metal or due to variations on the oxidized layer's surface, such as a crack, finishing, incrustation of factory lamination, direct pollution, etc. In this type of corrosion, the upper part of the metal has access to oxygen in the air and creates the cathode. In the pitted bottom, oxygen is reduced and the metal creates the anode, since the oxygen available is lower and the corrosion speed increases. Other types of corrosion present throughout the useful life of filtration tanks are: crevice corrosion [5], stress corrosion, biological corrosion, wear corrosion, galvanic corrosion, and atmosphere corrosion.

As for the supply of drinkable water in Mexico City and water treatment plants in Mexico City, it should be known that this has always been a problem for both inhabitants and administrators. In the middle of the Nineteenth Century, exploitation of underground water began with artesian wells. Then, springs near the city (Desierto de los Leones and Santa $\mathrm{Fe}$ ) were used. In recent years, water has had to be imported from far-away basins and extracted from deep wells. This has corresponding negative consequences-soil subsidence, weather changes and loss of biodiversity. As water supply is such a problem, consideration about its quality often comes second.

In order to cover the high demand of water, caused by increasing population and the resulting economic activities, the possibility of finding a large supply has been explored. The main source of water supply water to Mexico City has been the large auriferous underlying the city. However, from the beginning of the $20^{\text {th }}$ century, extensive exploitation of this body of water has caused holes and differential subsidence in the area. This threatens to cause salinization of the resource due to low recharge levels.

The inefficient use of water and its lack of treatment have resulted in insufficient surface sources, overexploited auriferous and most of the bodies of water and many auriferous being polluted. In addition, monetary charges for water are not appropriate and water is not duly measured. It has been estimated that $55 \%$ of water is wasted in the agricultural sector (out of $78 \%$ of the water), and $40 \%$ of water is wasted in urban areas (which consumies $12 \%$ of the total consumption [6] [7].

\section{Physic-Chemical Characterization}

Related to the influence of well water components in the corrosion behavior of filtering tanks, Table 1 shows two strong metals, iron and manganese, with high 
Table 1. Physic-chemical characterization of influent and effluent water Iztapalapa treatment plant [9].

\begin{tabular}{|c|c|c|c|}
\hline Parameter & $\begin{array}{c}\text { Limit value } \\
\text { NOM-127-SSA1-1994 }\end{array}$ & $\begin{array}{l}\text { Influent } \\
\text { Well }\end{array}$ & $\begin{array}{c}\text { Effluent } \\
\text { treatment plant }\end{array}$ \\
\hline Temperature & & 24 & 24 \\
\hline $\mathrm{Fe}$ & $0.30(\mathrm{mg} / \mathrm{l})$ & 0.428 & 0.28 \\
\hline $\mathrm{Mn}$ & $0.15(\mathrm{mg} / \mathrm{l})$ & 0.272 & 0.16 \\
\hline Ammoniacal-N & $0.50(\mathrm{mg} / \mathrm{l})$ & 1.06 & 0.40 \\
\hline Proteic-N & $0.10(\mathrm{mg} / \mathrm{l})$ & 0.17 & 0.11 \\
\hline Color & $20(\mathrm{Upt} / \mathrm{co})$ & 30 & 10 \\
\hline Turbidity & $5(\mathrm{UTN})$ & 9.82 & 4.16 \\
\hline Electric cond. & $1500(\mu \mathrm{s} / \mathrm{cm})^{* * *}$ & 2894 & 2797 \\
\hline SDT & $1000(\mathrm{mg} / \mathrm{l})$ & 1447 & 1204 \\
\hline Total hardness & $500(\mathrm{mg} / \mathrm{l})$ & 333 & 276 \\
\hline Total alkalinity & $400(\mathrm{mg} / \mathrm{l})^{\star *}$ & 711 & 420 \\
\hline D. Q. O & $4(\mathrm{mg} / \mathrm{l})$ & 16.8 & 10.0 \\
\hline $\mathrm{Na}$ & $200(\mathrm{mg} / \mathrm{l})$ & 310.8 & 120 \\
\hline Mg hardness & $125(\mathrm{mg} / \mathrm{l})$ & 251 & 192 \\
\hline Ca hardness & $30(\mathrm{mg} / \mathrm{l})^{* * *}$ & 112 & 72 \\
\hline $\mathrm{Ba}$ & $0.7(\mathrm{mg} / \mathrm{l})$ & & \\
\hline $\mathrm{PH}$ & & 7.96 & 8.08 \\
\hline Chlorides & 250 & 268 & 214 \\
\hline Standard count & $200(\mathrm{col} / \mathrm{ml})^{*}$ & 6500 & \\
\hline Total coliforms & $0(\mathrm{col} / \mathrm{ml})$ & 100 & 10 \\
\hline Fecal coliforms & $0(\mathrm{col} / \mathrm{ml})$ & 0 & 0 \\
\hline Phosphates & & 2.00 & 2.11 \\
\hline Sulfides & & 0.6 & 0.5 \\
\hline Sulfates & & 125 & 124 \\
\hline Free residual $\mathrm{Cl}_{2}$ & $0.2-1.5(\mathrm{mg} / \mathrm{l})$ & & 1.07 \\
\hline Total residual $\mathrm{Cl}_{2}$ & & & 2.5 \\
\hline $\mathrm{ICA}^{* * *}$ & $\leq 1.00$ & 1.93 & 1.40 \\
\hline
\end{tabular}

Note $1 .\left(^{*}\right)=$ Value guide from the federal regulation of water supply works potable 1952. $\left({ }^{* *}\right)=$ Value guide taken from the Mexican water and ice rules, laws, and codes for human and refrigeration use and consumption. Chapter 1, water, 1988; $\left.{ }^{(* *}\right)=$ Value guide taken from criterion to sanction quality of potable D.G.C.O.H 1995. Detection limits $\mathrm{cd}<0.0001, \mathrm{pb}<0.00059, \mathrm{Cr}<0.05, \mathrm{As}<0.00062, \mathrm{Cu}<0.026, \mathrm{Hg}<$ $0.00035, \mathrm{Al}<0.358<0.5$ (1996). Note 2 . Data taken from water quality record. Iztapalapa treatment water 1. Average date from the second half of 2007. Water quality laboratory. Potabilization and disinfection U.D. A. S.A.C.M.-S.M.A.-G.D.F.

influent values: $0.428 \mathrm{mg} / \mathrm{l}$ for iron and $0.272 \mathrm{mg} / \mathrm{l}$ for manganese. Regarding effluent, the $0.02 \mathrm{mg} / \mathrm{l}$ value is lower than the limit for iron, and $0.01 \mathrm{mg} / \mathrm{l}$ higher for manganese, which defines the standard for both cases. In addition, this 
shows that industrial activity exists in the area where the well is located. Once purification processes and outflow to be rendered drinkable are determined, reinforced concrete, steel or other material is used to construct tanks, sumps, containers, etc. Figure 2 shows the location of 16 water treatment plants in the eastern and southern areas in Mexico City, the operation area, as well as the corresponding boroughs [6] [7] [8]. Table 1 shows physic-chemical characterization of influent water or well and effluent or treatment plant.

Let us now see the influence of well water components on corrosive behavior of filtration tanks, through values of physic-chemical characterization of water registered in Table 1. Two strong metals were found, iron and manganese, which influent values are high: $0.428 \mathrm{mg} / \mathrm{l}$ for iron and $0.272 \mathrm{mg} / \mathrm{l}$ for manganese. From the effluent water point of view, $0.02 \mathrm{mg} / \mathrm{l}$ value is lower than the limit value for iron and higher than the limit value for manganese in $0.01 \mathrm{mg} / \mathrm{l}$ [8]. In both cases, it marks the norm, and it is indicative that there is industrial activity within the well's area. These concentrations of strong metals are indicators of the same damage and corrosion process already present in the tank, as well as of the gradual detachment of metals inside of it. As for the influent, those concentrations may also be due to the damage and corrosion process of pipes feeding the well.

Turbidity of water is the optical effect generated when the beams are dispersed or interfered with as they go through a sample of water, due to mineral or organic particles the liquid may contain as a suspension, such as microorganisms, clay, various oxide precipitations, precipitated calcium carbonate, aluminum compounds, et cetera. This effect is generally used as a way to control raw waste water and to characterize the efficiency of secondary treatment, once it is related to concentration of suspended solids. Its maximum allowable limit in drinkable-

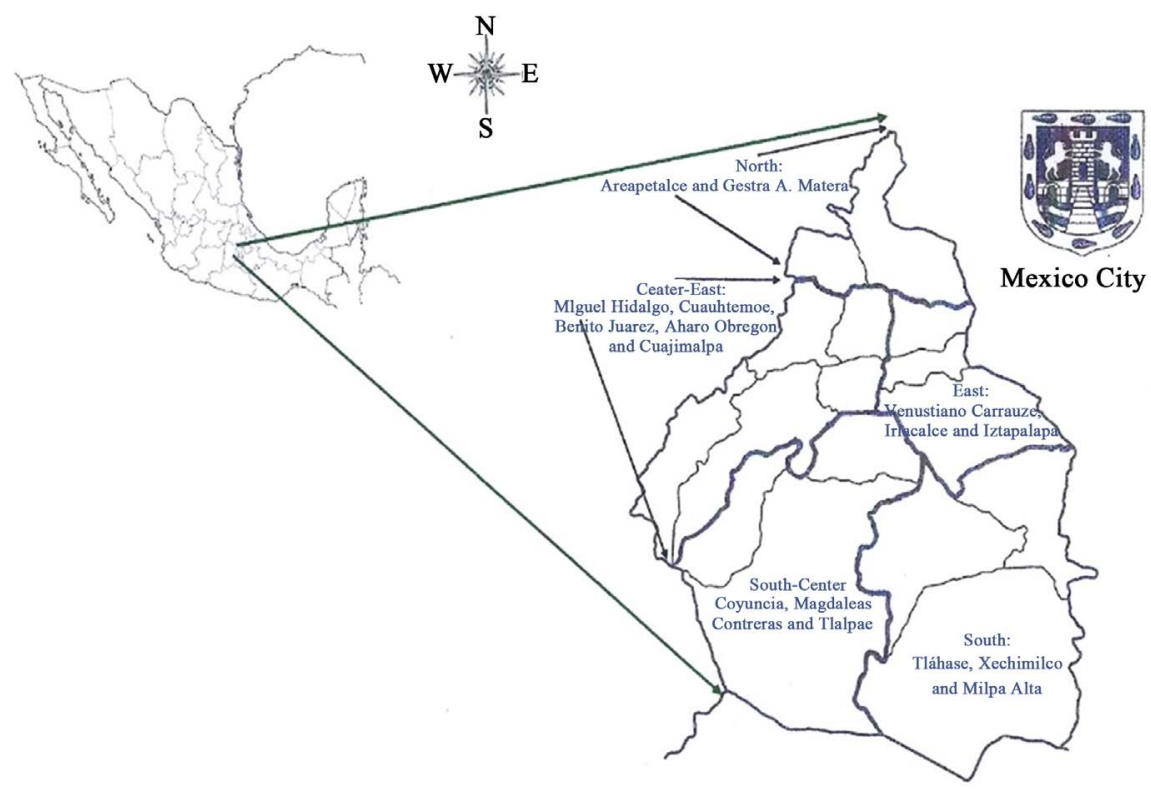

Figure 2. Areas in the Mexico City for operation of potable water infrastructure [7]. 
water is 5 NTU (Nephelometric Turbidity Units). A high turbidity value indicates the probable presence of organic matter and microorganisms increasing the quantity of chlorine or ozone used for disinfection of waters for supply of drinkable water. In our case, the turbidity value in its influent part is near the maximum allowable limit. Electrical conductivity of the well under study, showing the presence of dissolved solids, as well as alkalinity, shows high values. The total dissolved solids value is also high, both for its influent and effluent parts. These four parameters together show the existence of inorganic salts in the well. In addition, with the Chemical Oxygen Demand or COD value high; the $\mathrm{pH}$ shows considerable variations towards alkalinity. A 7 Units $\mathrm{pH}$ is neutral; in our case, the influent is 7.96 Units $\mathrm{pH}$ and the effluent is 8.08 Units pH. High alkalinity is due to other factors such as chemical reactions among existing particles, resulting in $\mathrm{pH}$ tending to be basic. Turbidity shows the presence of suspended solids. High COD values indicate pollution by organic and inorganic particles susceptible to be oxidized by potassium dichromate or permanganate coming from turbidity, dissolved solids, and/or electric conductivity.

Hardness is the chemical feature of water determined by the content of carbonates, bicarbonates, chlorides, sulfates and, occasionally, calcium and manganese nitrates. It is known that it is undesirable in domestic and industrial washing processes, since it causes more soap to be used, producing insoluble salts. In boilers and systems cooled with water, this means: incrustations in pipes, obstruction and loss of efficiency of heat transfer, water having a disgusting taste and, in addition, through time, pitting corrosion appears-though it takes time for this type of corrosion to cause real problems in these facilities, see https://www.nace.org/Pitting-Corrosion/. High hardness values are undesirable and should be removed before water may be properly used. Most drinkable water supplies have an average of $250 \mathrm{mg} / \mathrm{l}$ hardness, but in this well, stricter parameters of $125 \mathrm{mg} / \mathrm{l}$ for manganese and $30 \mathrm{mg} / \mathrm{l}$ for calcium have been established. In our case, hardness values surpass the established limit values. Even though, corrosion by $\mathrm{pH}$, calcium, manganese, and microorganisms is discarded.

As for chlorides, the maximum acceptable amount for drinkable water is 250 $\mathrm{mg} / \mathrm{l}$, but for human use it is recommended from $100 \mathrm{mg} / \mathrm{l}$ through $140 \mathrm{mg} / \mathrm{l}$. while here it is present in a $268 \mathrm{mg} / \mathrm{l}$ through $214 \mathrm{mg} / \mathrm{l}$ range [8]. Water with high oxidizability, ammonia, and nitrate and nitrite tenor characterizes pollution and, therefore, chlorides have such origin. If these substances are lacking, such high tenor often is due to the fact that water goes through land rich in chlorides. However, we do not believe that this is true in our case. Its values pollute the air and are corrosive. Chlorates are soluble in water, pollute it, and, with organic composites, they produce explosive mixtures. Based on this interpretation of data, corrosion by $\mathrm{pH}$, calcium and manganese, as well as by microorganisms, is discarded. The fact that the container works under pressure, which makes corrosion slower, must be taken into account.

After the first 8 years of operation of the eastern system water treatment 
plants in Mexico City, 3 out of 10 filters showed exceedingly high corrosion inside the filtering tanks with A284 Grade C steel plates and e $=9.8 \mathrm{~mm}$ wall thickness. Indeed, the corrosion rendered the filters useless. This problem made evident the need to conduct experiments regarding the evolution of corrosion and the structural behavior of the tank damaged by corrosion within the laboratory. Such damage by corrosion generates a local failure in the joint of the false bottom, supporting filtering material, with the wall of the auto-supported tank. Such local failure causes total and/or partial suspension of the drinkable water supply to Mexico City, see https://www.steelconstruction.info/Corrosion_of_structural_steel.

Due to the functioning of such pressurized steel tanks, it is not possible to periodically check the evolution of corrosion inside them: the operation filtering tank would have been suspended, thus affecting the drinkable water supply for up to forty days, i.e. the period required to remove filtering material and properly check the false bottom and the wall of the tank. We move now to look at the development of the experiment, in order to obtain data related to corrosion in the wall of the damaged filtering tank within a determined period of time; damage analysis, both mechanical and by corrosion; corrosion speed assessment; and discussion of results.

\section{Assessment of Corrosion Speed}

The degree of corrosion of the samples under study has been assessed through corrosion speed, basically defined as metal mass loss per surface and time unit, Equation (1):

$$
V c=\frac{\text { Metal mass loss }}{\text { Surface } * \text { time }}
$$

where $V c$ is corrosion speed and its units may be expressed in various manners. One is: $\left[\mathrm{g} / \mathrm{cm}^{2} \cdot\right.$ year $]$ Consequently, determination of corrosion speed is made through weight loss. In real structures, this is only possible to ascertain if a small part of corroded structure is cut, having previously been cleaned, weighed, and is said weight is subtracted from the starting weight obtained from a material sample and metal density.

Since in (1) the profile exposure surface value is involved, Table 2 shows features of test tubes under analysis. Analyzing the general behavior of corrosion speed obtained from structural profiles, it was found that the corrosive phenomenon shows its maximum activity through three years of exposure. The total corrosion or mass loss undergone by metallic material was intended to be quantified using climatic factors. However, it was not possible to apply such criterion due to lack of available meteorological data. Relative humidity periods equal to or higher than $80 \%$ must be present, and unfortunately, the number of available data was lower. Due to this, the data is not sufficiently representative to validate this criterion [10] [11]. 
Table 2. Features of test tube obtained from a tank made of Steel A284 Grade C, used in filtration of deep well water.

\begin{tabular}{cccccc}
\hline $\begin{array}{c}\text { Test } \\
\text { tube }\end{array}$ & $\begin{array}{c}\text { Starting } \\
\text { weight (gr) }\end{array}$ & $\begin{array}{c}\text { Weight before } \\
\text { to pickling (gr) }\end{array}$ & $\begin{array}{c}\text { Weight after } \\
\text { to pickling }(\mathrm{gr})\end{array}$ & $\begin{array}{c}\text { Exposed } \\
\text { surface }\left(\mathrm{cm}^{2}\right)\end{array}$ & $\begin{array}{c}\text { Corrosion speed } \\
\mathrm{gr} / \mathrm{cm}^{2} \cdot \text { year }\end{array}$ \\
\hline 1 & 111.40 & 125.21 & 124.30 & 61.28 & 0.042 \\
2 & 112.514 & 126.32 & 125.36 & 62.18 & 0.044 \\
3 & 139.25 & 155.19 & 154.05 & 76.24 & 0.043 \\
4 & 74.048 & 81.29 & 81.00 & 43.60 & 0.019 \\
5 & 137.44 & 151.58 & 150.62 & 47.11 & 0.058 \\
6 & 122.169 & 134.53 & 134.19 & 52.51 & 0.018 \\
7 & 117.738 & 129.01 & 128.69 & 50.32 & 0.018 \\
8 & 82.69 & 91.20 & 90.20 & 58.70 & 0.049 \\
9 & 72.84 & 80.33 & 79.28 & 49.78 & 0.060 \\
10 & 90.60 & 99.92 & 98.82 & 61.50 & 0.051 \\
11 & 111.2 & 123.15 & 122.13 & 60.74 & 0.0153 \\
12 & 111.4 & 123.57 & 123.05 & 60.74 & 0.078 \\
\hline
\end{tabular}

In accordance with data obtained, an acceptable corrosion speed was determined for test tubes made of steel A284 Degree C lower than $0.2 \mathrm{~mm} / \mathrm{year}$. This speed considers that, in a similar period after 8 years of operation, the structure shall keep a good corrosion speed, since corrosion composites create a passivation layer controlling and inhibiting corrosion. This expects for proper behavior of the structure, even if it loses all the coating due to corrosion. This is in accordance with the Rules for Buildings in Mexico City, which is 1/6 of plate thickness calculated, in this case, a $3 \mathrm{~mm}$ increase [12]. The corrosion criteria Table 2 by [13] was taken as a reference. Since the plate is subject to tensile stress, failures due to corrosion under stress may occur (stress corrosion cracking). However, this type of failure was not found upon checking the tank.

\section{Conclusions}

Physic-chemical characterization of well water shows strong metals: steel, and manganese, with high values: $0.428 \mathrm{mg} / \mathrm{l}$ for steel and $0.272 \mathrm{mg} / \mathrm{l}$ for manganese; such concentrations show damage and corrosion resulting in a progressive detaching of metals inside the containers already studied [1].

Electrical conductivity and total alkalinity values obtained in the study, which show the presence of dissolved solids, imply high values. In like manner, the total dissolved solids value is high both in its influent and effluent parts. These parameters together show the probable existence of inorganic salts in the area under study. The influent value is $7.96 \mathrm{U} \mathrm{pH}$ and the effluent value is $8.08 \mathrm{U} \mathrm{pH}$. High alkalinity is due to factors such as chemical reactions among existing particles generating $\mathrm{pH}$ tending to be basic. Turbidity shows the presence of suspended solids. High DQO values show pollution due to organic and inorganic 
particles that may be oxidized by potassium dichromate or permanganate from turbidity and dissolved solids and/or electric conductivity.

Most drinkable water supplies within the area have a $250 \mathrm{mg} / \mathrm{l}$ average hardness but here, a strict parameter has been defined from its origin: $125 \mathrm{mg} / \mathrm{l}$ for magnesium and $30 \mathrm{mg} / \mathrm{l}$ for calcium. In our case, the hardness values are over the defined limit values. That said, corrosion due to $\mathrm{pH}$, calcium, magnesium, and microorganisms is rejected. As it has been said, the maximum of chlorides acceptable in drinkable water is $250 \mathrm{mg} / \mathrm{l}$, but it is recommended that, for human consumption, it ranges from $100 \mathrm{mg} / \mathrm{l}$ through $140 \mathrm{mg} / \mathrm{l}$. Here, chlorides are within an interval from $268 \mathrm{mg} / \mathrm{l}$ through $214 \mathrm{mg} / \mathrm{l}$. Finally, from this interpretation of data, corrosion due to $\mathrm{pH}$, calcium, magnesium, and microorganisms is rejected. It must be taken into consideration that containers work under pressure, which renders corrosion slower.

Based on bacteriological results for drinkable water, it is of paramount importance to carry out proper samplings. In accordance with results obtained, it may be said that there is a good bacteriological quality in most sampling sites (wells). Finally, analytical results in surface water depend on the number and type of discharges, their composition, degree of urban, industrial or agricultural growth, and the season.

\section{Acknowledgements}

This article its corresponding research was carried out, in part, with the research projects IPN-SIP-20080512, IPN-SIP-20090376 and IPN-SIP-20171058. The author is very grateful to the reviewers for carefully reading the paper and for their constructive comments and suggestions which have improved the papers. I also thank Professor Moises Gaytán-López for his contribution to this study.

\section{References}

[1] Casanova-del-Angel, F. and Gaytán-López, M. (2015) Analytical Model on Steel Tanks Damaged by Corrosion. World Journal of Mechanics, 5, 274-285. https://doi.org/10.4236/wjm.2015.512026

[2] Casanova-del-Angel, F. and Toquiantzi-Butrón, R. (2008) Corrosion Phases of Structural Shapes Exposed to the Atmosphere. Corrosion Science, 50, 2288-2295. https://doi.org/10.1016/j.corsci.2008.05.015

[3] José., M.T., Uruchurtu, C., Meza, B., López, G. and Luis, F. (2003) Evaluación de la problemática de corrosión en fondos de tanques de almacenamiento de petróleo crudo. Terminal marítima de dos bocas. Boletín IIE del Instituto de Investigaciones Eléctricas. Aplicaciones Tecnológicas, pp. 11-18. January-March 2003. México. https://www.ineel.mx//boletin012003/aplica1.pdf

[4] Kirkwood, J.P. (1869) Report of the Filtration of River Waters. New York d. Van nostrand publisher, London. Document digitized by the Internet Archive in 2007 with funding from Microsoft Corporation. https://archive.org/details/reportonfiltrati00kirkrich

[5] Rashidi, N., Alavi-Soltani, S. and Asmatulu, R. (2007) Crevice Corrosion Theory, Mechanisms and Prevention Methods. Proceedings of the 3rd Annual GRASP Symposium, Wichita State University, 27 April 2007. 
[6] DGCOH (1995) Criterio para sancionar la calidad de agua potable. Dirección General de Construcción y Operación Hidráulica. Secretaría de Obras y Servicios. DDF. Mexico.

[7] Plan 2010 (2010) Maestro de Agua Potable del Distrito Federal 1997-2010. Departamento del Distrito Federal. Secretaría de Obras y Servicios. Dirección General de Construcción y Operación Hidráulica. Dirección Técnica. Subdirección de Programación. Unidad Departamental de Planes Maestros. Mexico.

[8] NOM-127-SSA1. NORMA OFICIAL MEXICANA (1994) Salud Ambiental, Agua para Uso y Consumo Humano-Límites Permisibles de Calidad y Tratamientos a que debe Someterse el Agua para su Potabilización. Secretaría de Salud. Mexico. Date of publication: November 22, 2000.

[9] Fair, G.M., Geyer, J.C. and Okun, D.A. (1979) Purificación de agua y tratamiento y remoción de aguas residuals. Volume II. Editorial LIMUSA. Mexico. ISBN: 968-18-0167-9.

[10] Koteš, P., Brodňan, M. and Bahleda, F. (2016) Diagnostics of Corrosion on a Real Bridge Structure. Advances in Materials Science and Engineering, 2016, 1-10. https://doi.org/10.1155/2016/2125604

[11] Rodriguez, A.A., Monty, C.N., Miller, C.M., Cong, H. and Wujcik, E.K. (2016) Laboratory Techniques for Evaluating the Effectiveness of Salt Neutralizers for the Corrosion Prevention of Winter Maintenance Equipment. Anti-Corrosion Methods and Materials, 63, 499-507. https://doi.org/10.1108/ACMM-03-2015-1516

[12] RCDF (1993) Reglamento de Construcciones para el Distrito Federal. August 3, 1993 in Diario Oficial de la Federación. Artículo 2, § XII. Departamento del Distrito Federal. México.

[13] Fontana, M.G. (1986) Corrosion Engineering. McGraw Hill, New York. 